\title{
HUMAN FATE AND DIVINE WILL IN THE THEOGNIDEA ${ }^{1}$
}

\section{J.H. Barkhuizen, University of Pretoria}

The term "Theognidea" or Corpus Theognideum represents the 1389 lines ascribed to the poet Theognis, although we know that not all of these lines come from the hand of Theognis himself. For this reason I will constantly refer to the poems in this corpus as "Theognidea" rather than "the poems of Theognis" (cf. West 1974:40-45; 65-71; Adkins 1985:133).

The Corpus Theognideum is divided into two books (1-1230; 1231-1389), the first being both the longest and most interesting of the two, containing a variety of themes, of which the sociopolitical is probably the most important. The most recent and complete study on this aspect is that of Figueira and Nagy (1985). One theme that also recurs frequently within book I, and one indeed occurring frequently in Greek literature in general, and especially early Greek poetry, concerns the viewpoint on the vicissitudes of human life (Adrados 1959:113). An integral part of this theme is the relation between the vicissitudes of human life and the will of the gods, or often merely that of Zeus, whose will is perceived as representing the highest order of the divine will. It is this latter theme which concerns us in this paper.

It would perhaps be well to take as starting-point for our cursory analysis of this theme in the Theognidea the famous passage in Iliad 24, because this passage has come to be regarded as perhaps the locus classicus of this theme. I refer here to lines 527-533:

For two urns are set upon the floor of Zeus of gifts that he gives, the one of ills, the other of blessings.

To whomsoever Zeus, that hurleth the thunderbolt, gives a mingled lot, that man meets now with evil, now with good;

but to whomsoever he gives but of the baneful, him he makes to be reviled of man, and direful madness drives him over the face of the sacred earth and he wanders honoured neither of gods nor mortals.

(Murray 1957:601-602)

It is especially the first part of this passage that has influenced subsequent views on this matter: the man who receives from Zeus a mingled lot, experiencing now blessings, now ills. This can be clearly seen in Theognidea 157-158, in which the image of the two urns of Iliad 24.527 is replaced with the image of the balance: 2

Zeus tilts his balance this way and then that, One moment you're a rich man, next you're not.

Lines 133-134 of the Theognidea express this same idea in non-metaphorical language:

No mortal, Kurnos, makes his own success,

Nor his own ruin, for the gods bring both;

Paper read at the 19th CASA Conference, University of Cape Town, January 1991.

2 All translations from the Theognidea are taken from Wender (1977). 
while in lines $165-166$ the divine will is replaced by the concept of man's $\delta \alpha i \mu \omega \nu$, "a sort of patron spirit" (Wender 1977:159):

No man is rich or poor, or good or bad

Unless his private daimon makes him so.

From these passages, and many others, it is clear that man's fate inevitably rests in the hands of the gods, and as the poet of lliad 3.65-66 puts it, no man, by his own will, can win these gifts of the gods.

This, of course, has some important implications for the Greek mind, and in this instance for the thought-world presented in the first book of the Corpus Theognideum. The analysis of a few of these implications will suffice to show the importance of the Theognidea as source for a detailed study of this theme in early Greek literature.

1. One of the most obvious of implications resulting from this relation is the emphasis on the power of the gods vs the utmost helplessness of mortal man.

The poet of Theognidea 617-618 expresses it in no uncertain terms as follows:

Men do not often get their heart's desire:

Gods are more powerful than mortal man.

This reminds us of a passage in the Hymn to Demeter, lines 147-148, in which Callidice, one of Celeus' daughters, speaks as follows:

Mother, what the gods send us, we mortals bear perforce, although we suffer; for they are much stronger than we are.

(Evelyn-White 1967:299)

And Semonides formulates this same idea in the first two lines of one of his poems, known as Fragment $1 \mathrm{~W}$, in terms which clearly underline Zeus' power:

Loud-thundering Zeus holds the end

of all that exist, in his hands, and he directs it as he wishes.

In connection with this emphasis on the gods' power in all things pertaining to human life, the poet of the Theognidea warns his audience/listener not to swear "That thing will never be!", for the gods might take offence, since they have power over the end (659-660); or again he advises people to pray to the gods, for they have all the power, and all good and evil come to men from them (171-172).

2. Closely related to this is the concept of man's lack of knowledge and foolish yearning for things unattainable. The locus classicus of this concept in the Theognidea is poem 133-142, of which I have already quoted the first two lines. Lines $135 \mathrm{ff}$ read as follows:

There is no man who knows at heart

If in the end he works for good or bad.

Often he thinks he'll fail, and then he wins,

Often expects to win - and then he fails. 
No one gets all he wants; all men stop short, Checked by the boundaries of the possible.

We think our thoughts in vain, all ignorant,

The gods do everything just as they want.

While the first part of the poem refers to the vicissitudes of human life, the second part relates to the cause, the reason behind this: the ignorance of man as opposed to the powerful will of the gods, who act according to their wishes. This point of view is expressed in 585-590 in much the same vein:

There's risk in everything, and no one knows

When he conceives a plan, where it will lead.

One man who's bent on reputation falls

Through lack of foresight into great and painful doom,

Another, doing good, is given by god

happy fortune in all things, liberating him from foolishness 3

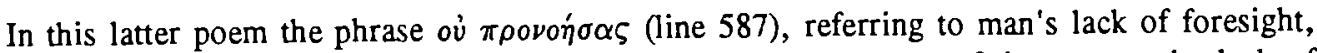
has as ultimate result $\dot{\alpha} \phi \rho \circ \sigma u ́ \eta \eta$ (line 590), which forms the core of the matter: the lack of knowledge, of $\pi \rho o$ vor $\alpha$, in mortal man is linked to the fact that in everything he is hampered by the boundaries of his helplessness: the $\pi \epsilon i \rho \alpha \tau^{3} \alpha \mu \eta \chi \alpha \nu i \eta \zeta \quad(140$ and 1078; see also Archilochus $128 \mathrm{~W}, 1)$. This motif reminds us of the famous fragment of Semonides (1W) quoted above. We have heard how in the very first two lines Semonides acclaims the power of Zeus who holds all in his hands and directs all according to his will. This divine power is emphasized in the rest of this poem (lines 2-24) by reference, as antithesis to the power of the gods, to the lack of knowledge in the heart of mortal man. Semonides uses an image which modern idiom knows well, when he compares men with sheep. We mortals, he says, are like sheep, having no knowledge, not knowing how god, i.e. Zeus, will bring each thing to fulfilment. The problem becomes more complex because of the fact that mortals, despite their

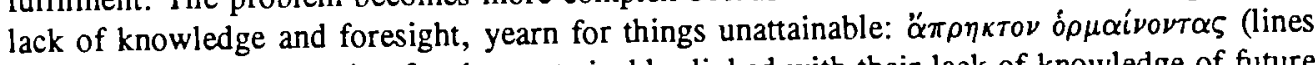
$5-6$ ). For it is this yearning for the unattainable, linked with their lack of knowledge of future events, which eventually and by neccessity leads to misery and misfortune and failure to attain what they desire.

Another poem expressive of this concept is Theognidea 1075-1078:

It's very hard to know how god will end

Events yet unperformed. We cannot see

Where our perplexity will stop, before

The future happens. Darkness covers us.

Again the poet combines the concept of man's lack of knowledge (ou $\xi u v \epsilon \tau \dot{\alpha}, 1078$ ) with the concept of man's helplessness ( $\pi \epsilon i \rho \alpha \tau^{\prime} \alpha \mu \eta \chi \alpha \nu^{\prime} \eta \eta 5,1078$ ), while in line 1077 he uses the

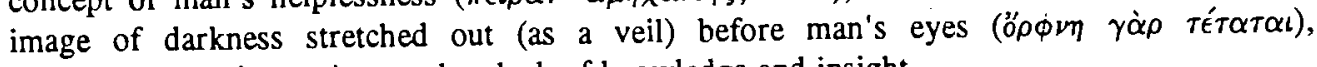
emphasizing again man's complete lack of knowledge and insight.

The translation of Wender has been altered by the author in two instances. 
3. A final implication of this relation between human fate and divine will is that man cannot escape the fate which the gods have ordained for him. A short poem, lines 1187-1190, illustrates this aspect in a nutshell:

No one by paying ransom can escape

Death or misfortune, if it's not his fate.

Nor can man escape anxiety

By bribery, when god sends pain to him.

Broadly speaking a threefold solution to this problem of the inescapability of man's fate has been propounded:

3.1 One approach relates to the concept of carpe diem: the call to enjoy one's life. In Theognidea 1047-1048, for instance, the poet lightheartedly advises his audience to drink and enjoy themselves, for the gods will see to what comes next (1047-1048).

3.2 A more serious approach relates to the concept of endurance, a concept we may call the $\tau o ́ \lambda \mu \eta$ motif, i.e. man is urged to endure whatever gifts the gods bestow on him. This is one of the most important motifs within this theme in ancient Greek literature from Homer onwards, although, of course, it must be stated clearly, that it is often seen from a different perspective, as the context in which it occurs, varies. Note that part and parcel of this motif is the idea of $\chi \rho \dot{\eta}$, the "must" of man's endurance, and the phrase $\chi \rho \dot{\eta} \tau o \lambda \mu \hat{\alpha} \nu$ often occurs in this connection in the Theognidea.

One of the most important early texts expressive of this motif is fragment $13 \mathrm{~W}$ of Archilochus. Archilochus, referring to a disaster at sea during which some excellent citizens perished, amongst whom probably also his brother-in-law, writes as follows (lines 5-7):

But the gods have given us for our incurable misfortunes, my friend, $\kappa \rho \alpha \tau \epsilon \rho \grave{\eta} \nu \tau \lambda \eta \mu \circ \sigma u ́ v \eta \nu$ as cure.

And this cure lies precisely in the knowledge that the gods give both good and bad, and that they give these gifts now to this man, now to that. This concept of oscillation between good and bad, closely related to the idea that the gifts of the gods to man are of all sorts, has first been identified as such by $\mathbf{H}$ Fränkel (1975:493, note 16), referring to it as the so-called pendulum concept. Fragment $13 \mathrm{~W}$ of Archilochus, quoted above, can perhaps be classified as the locus classicus of this concept: in lines 7-9 the poet says that pain is bearable because we know that mankind suffers intermittently. It is because mankind experiences joy and pain alternately, that life becomes bearable.

Archilochus, as indicated above, uses for this motif of endurance the word $\tau \lambda \eta \mu o \sigma v i \eta$, which is a new expression, but obviously related to the verb $\tau \lambda \alpha \alpha^{\prime} \omega$ or $\tau 0 \lambda \mu \alpha \omega$, used by several poets in this connection, inter alia Homer. It also occurs in the Theognidea, although Van Rooy (1986:10, 14-15) has argued that $\tau \lambda \eta \mu \circ \sigma u v \eta$ in Archilochus signifies much more than merely passive endurance in the Homeric sense of this verbal group. It rather implies the meaning of "bringing oneself to do something contrary to one's feelings ..., have the courage" (Van Rooy

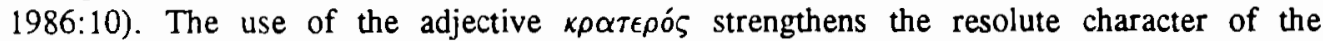
expression (see also Adkins 1985:40). This is confirmed by line 10, in which the poet refers to the pain which one must throw off in this process of active endurance, with the significant adjective $\gamma v \nu \alpha \iota x \in \hat{\epsilon} \circ \nu$ (line 10). 4 
In the Theognidea, the following poems contain this $\tau \dot{0} \lambda \mu \eta$ motif, and a close reading of these poems suggests that the poet of these lines was perhaps influenced by the Archilochean sense of the concept of endurance.

(i) Lines $355-360$

Have courage now in bad times, as you had

Delight when fortune, Kurnos, favoured you;

Your luck was good, then bad; now try to escape

from the sea of misfortune, 5 with god's help.

But do it in the dark; too much display

Of misery will bring few comforters.

(ii) Lines $441-446$

No one is always lucky in all things;

Good men endure bad luck without complaint, The common man cannot control himself In good times or in bad. All sorts of gifts Come to us mortals from the gods; we must

Endure, whatever sorts of gifts they give.

(iii) Lines 555-556

The man who lies in sore pain must be brave And ask the deathless gods for his release.

(iv) Lines 591-594

Men must endure whatever the gods give And lightly bear our share of good and bad, In bad times not too sick at heart; in good Not glad too soon, before we see the end.

(v) Lines 1029-1036

Be brave, my soul, although in these hard times

You suffer things unbearable. The hearts

Of common men are quick to be distressed.

Don't make your pain the worse by worrying

About what can't be done; don't vex yourself,

5 I have in lines 357-358 "corrected" the translation of Wender, who translates: "to slip out of misfortune's garment". 
Don't grieve your friends and please your enemies.

A mortal man can't easily escape

The destined gifts of gods, not if he goes

To the very bottom of the purple sea

Nor if he lies in misty Tartarus.

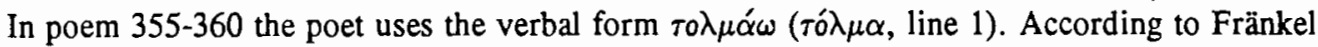
it is "a specific form of courage and resistance ... a strong and composed attitude of mind; a spirit of resistance which sets the oppressed on his feet again" (Fränkel 1975:421). The poem is therefore, as Henderson indicates (Henderson 1986:190), neither pessimistic nor fatalistic. The fact that man cannot escape his fate (cf. poems 1029-1036 and 1187-1190, quoted above) may therefore seem to carry with it a tone of fatalism, but the poet rather uses this motif to encourage himself to face life with a resolute spirit.

In both poems $441-446$ and 1029-1036 the poet employs another motivation for endurance, namely that the good man does not show his pain, but endures what the gods give. It is the coward who shows his pain, and reveals a lack of temperance. This surely reminds us of Archilochus who urges his audience to throw off pain because pain ( $\pi \dot{\epsilon} \nu \theta 0 \varsigma$ ) belongs to the category " $\gamma u \nu \alpha$ «tiov" mourning as is shown by women (see above). It is possible that the

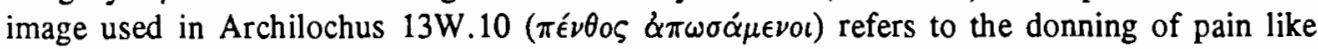

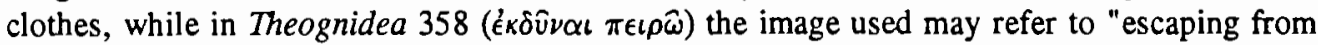
'a sea of troubles', a very common figure in Greek poetry..." (Hudson-Williams 1979:200). Related to this motivation is the one contained in poem 355-360, namely an aversion to displaying suffering in public. When people come to know a man as one who always displays his suffering in the open, or does this to an excessive degree, they develop an apathy towards such a person or his suffering.

Poem 555-556 also begins with the familiar phrase which is characteristic of this motif in the Theognidea: $\chi \rho \dot{\eta} \tau 0 \lambda \mu \hat{\alpha} \nu$. In the next line the poet links to this $\chi \rho \dot{\eta}^{\prime}$ a prayer motif: while man must endure his pain, he must also pray to the gods for release from his pain. In a previous poem, 171-172, the poet has also advised his audience to pray to the gods, for they have all the power, and only they can change his fate (Henderson 1986: 190).

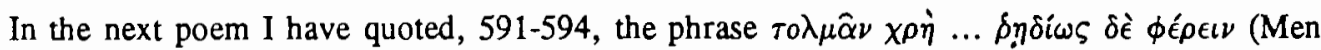
must endure ... and lightly bear) breathes the selfsame tone of courage in the face of that which

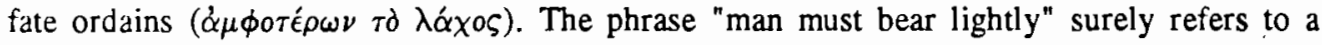
concept of active endurance, as opposed to an excessive show of pain and suffering on the one hand or cheer on the other hand, for the word $\rho \eta \delta i \omega \varsigma$ is defined by the poet with the warning not to be too sick at heart when suffering pain, nor to be of good cheer too soon, for the end of everything is in the hands of the gods; and: mortal man, as we are reminded in several important poems (see above), is without knowledge because he is checked by the boundaries of what is possible for him; or, put differently, by his utter helplessness.

3.3 A third approach to this problem, in strong contrast to the $\tau \delta \hat{\lambda} \mu \eta$ motif, is one characterized by a great measure of pessimism (Adrados 1959:113). In one famous little poem, lines $425-426$, the poet envisages the ultimate escape route from all man's misery as follows:

For man the best thing is never to be born, never to look upon the hot sun's rays.

$(425-426)$ 
But, if it is indeed man's fate to be born, the poet's second best option is death as soon as possible:

Next best, to speed at once through Hades' gates

And lie beneath a piled-up heap of earth!

However, from lines $1033 \mathrm{~b}-1036$ it is clear that this second best option offers little in the form of consolation:

A mortal man can't easily escape

The destined gifts of the gods, not if he goes

To the very bottom of the purple sea

Nor if he lies in misty Tartarus!

To conclude: a cursory anajysis cannot do justice to such an important theme as the relation between human fate and divine will in early Greek literature, yet the main purpose of this overview was to underline the significance of the Theognidea as a link within this chain, and the need, perhaps, of a more detailed study of the religious perspective present in the Theognidea, and especially a perspective on what is surely one of the most universal of phenomena in human thought: how does divine will shape human fate, and how does human fate relate to the power and will of the gods?

\section{BIBLIOGRAPHY}

Adkins, A.W.H. 1985. Poetic Craft in the Early Greek Elegists, University of Chicago Press.

Adrados, F.R. 1959. Liricos Griecos. Elegiacos y Yambografos Arcaicos, II, Barcelona.

Barkhuizen, J.H., Henderson, W.J., and Van Rooy, C.A. 1986. Kalliope I. Griekse Jambiese en Elegiese Poësie van Archilochos tot Theognis. Pretoria: University of South Africa.

Evelyn-White, H.G. 1967. Hesiod, the Homeric Hymns and Homerica, Loeb Classical Library, London: Heinemann.

Fränkel, H. 1975. Early Greek Poetry and Philosophy, translated by M. Hadas and J. Wills. Oxford.

Henderson, W.J. in: Barkhuizen, Kalliope I.

Hudson-Williams, T. 1979. The Elegies of Theognis, New York: Arno Press.

Figueira, Th. J. and Nagy, G. 1985. Theognis of Megara. Poetry and the Polis. Baltimore: Johns Hopkins University Press.

Murray, A.T. 1957. The Iliad, Book II. The Loeb Classical Library. London: Heinemann.

Van Rooy, C.A. in: Barkhuizen, Kalliope I.

Wender, W. 1977..Hesiod and Theognis. England: Penguin Books.

West, M. 1974. Studies in Greek Elegy and Iambus 1. Berlin: De Gruyter. 